\title{
Jewish Education in Baghdad: Communal Space vs. Public Space
}

\author{
S.R. Goldstein-Sabbah
}

The Levant of the early twentieth century was a place of rapid political, social, and cultural transformation. This era ushered in a new, for lack of a more precise term, "modern" era for the region characterized, in part, by a burgeoning middle class and an increase in intercommunal dialogue that resulted from new forms of public space. ${ }^{1}$ The dissolution of the Ottoman Empire and the combining of three former Ottoman provinces - Baghdad, Basra, and Mosulinto a new Iraqi state led to numerous challenges in unifying an ethnically and religiously diverse population and caused decades of political instability. However the British mandate and early years of the Iraqi state are also viewed as a time of religious pluralism and an attempt to build an inclusive secular state $^{2}$ with the city of Baghdad as its political, cultural, and economic center.

In Baghdad, as in many other Middle Eastern cities, the modern era meant the creation of new public spaces, such as chambers of commerce, modern companies, hotels, and cinemas to name a few examples. ${ }^{3}$ One type of area not often associated with public space are schools run under the auspices of religious communities. However, in Baghdad, schools run by religious authorities were a key factor in forging the new national identity; they often served as public spaces and as public symbols for religious communities to demonstrate their belonging to the nation.

In Baghdad the first modern schools teaching secular subjects were established under the authority of religious communities. This is ironic when measured against conventional ideas of modernity and the role of modern education. In the case of the Jewish schools, as we would expect, these schools

1 Keith D. Wattenpaugh, Being Modern in the Middle East: Revolution, Nationalism, Colonialism and the Arab Middle Class (Princeton, NJ: Princeton University Press, 2006) for a full discussion on modernity and the middle class in the Middle East.

2 Orit Bashkin, The Other Iraq: Pluralism and Culture in Hashemite Iraq (Stanford, CA: Stanford University Press, 2008).

3 See Daniel Schroeter's chapter for a greater discussion on these new public spaces. I am grateful to Prof. Schroeter for his help and comments in putting together this chapter.

(C) S.R. GOLDSTEIN-SABBAH, 2016 | DOI: 10.1163/9789004323285_005 
strengthened a religious/ethnic (Jewish) consciousness. However, they also fostered a national (or public) consciousness, and facilitated the development of ties with the larger (non-Jewish) society. In one space, namely the schools, students developed a simultaneous awareness of both the communal and the public, thereby shattering the assumption of a dichotomy between "communal" (or sectarian) and public (or national) space.

In this chapter I look at the importance of education within the Jewish community of Baghdad as an example of how the boundaries between public and communal space became blurred beginning in the Mandate period. I argue that the Jewish schools of Baghdad had a fluid identity. The schools simultaneously strengthened the Jewish community's ties to the emergent Iraqi nation while fostering ties to the transnational Jewish world through their engagement with foreign philanthropic Jewish organizations. In this manner, the schools were a public platform for the community to show its integration into the new state and its desire to participate in its construction while leveraging and strengthening its ties with Jewish communities outside Iraq. I apply this thesis to the schools that fell under the jurisdiction of the Jewish community of Baghdad. ${ }^{4}$

4 This fact is demonstrated most clearly in the English language report from 1930 entitled Report of the Jewish Schools Committee on the Jewish Schools in Baghdad 1930. The report was most likely prepared for the Anglo-Jewish Association, to demonstrate how the association's contributions had been spent, and help make the case for allocating additional funds to the Baghdad schools. For this chapter I have also used a 1924 letter from the office of the chief rabbi to Judah Magnes while he was still living in New York (later, the first Chancellor of Hebrew University). The letter was written in response to a request for information on the Jewish community of Baghdad for the Jewish Encyclopedia and therefore describes in great detail the functioning of the Jewish community of Baghdad, and gives detailed information on its revenues and expenditures. Both of these documents describe the Jewish schools from the perspective of a communal leader wishing to present their community to Jews living outside Iraq and the tone is one which shows both the community's commitment to modernity and the preservation of Jewish culture. The two documents belong to the collection of material on the Jewish community of Iraq held at the Central Archive for the History of the Jewish people at the Hebrew University Givat Ram campus. For general demographic information I have taken the numbers used by Hanna Batatu in his The Old Social Classes \& the Revolutionary in Movement in Iraq (Princeton, NJ: Princeton University Press, 1978). For Jewish demographic information I have used Hayyim J. Cohen's book, The Jews of the Middle East: 1860-1972 (Jerusalem: Israel University Press, 1974), which contains demographic data on Levantine Jewry based on primary source material and surveys from the 1950s. The volume fortuitously contains a whole section dedicated to education in Iraq. For general information on Iraqi education I have used the numbers and curriculum details from the 1948 study by Roderic D. Matthews and Matta Akrawi commissioned by the American Council on Education; it also provides a summary history of education in Iraq beginning 
By looking at the evolution of these schools during the formative years of the Iraqi state, we can see how the community positioned itself vis-à-vis the state and other Jewish communities.

Although the type of education offered by these schools was diverse in nature I consider them as a single unit because of their dependence on the lay council for financial administration. Officially there was no singular unified Jewish school system but a grouping of schools that had varying attachments to either the spiritual council of the Baghdad Rabbinate (al-Majlis al-Ruhānī), or the Jewish Lay Council (al-Majlis al-Jismānī ), the two main official organs of the Jewish community. From the 1920 onward all of these schools were under the official jurisdiction of the "School Committee" which reported directly to the lay council ${ }^{5}$ a fact that coincides with a decline in the rabbinate's power over the community and a strengthening of the authority of the lay council. The school committee made decisions primarily related to the distribution of funds, though it also controlled some decisions on curriculum, and the hiring of faculty.

Communal reports from the era differentiate between four types of Jewish schools in Baghdad:

1. Religious schools, such as the Midrash Talmud Torah established in 1932, which was essentially a religious school with elementary studies in Arabic. After 1840 the Yeshiva of Baghdad ${ }^{6}$ offered religious education and, beginning in the early twentieth century, limited secular education. The Midrash Menashe Saleh school was founded in 1935 and offered both religious and secular subjects on a par with the Iraqi national curriculum. ${ }^{7}$

2. The Alliance Israélite Universelle girls and boys schools, based on a French curriculum.

3. The community schools followed a modified government syllabus teaching biblical Hebrew and Jewish history instead of Islamic studies, and added extra hours to the school week for English lessons (in comparison to the government schools).

4. The Shamash school, a community school based on the English curriculum.

during the Mandate Period. Finally, I have supplemented these sources with information from the autobiographies of students who attended these Jewish schools during the said period.

5 Cohen, The Jews of the Middle East, 122-123.

6 Orit Bashkin, "'Religious Hatred Shall Disappear from the Land' Iraqi Jews as Ottoman Subjects, 1864-1913," International Journal of Contemporary Iraqi Studies 4, no. 3 (2010), 308 (doi:10.1386/ijcis.4.3.305_1).

7 Cohen, The Jews of the Middle East, 115. 
Towards the end of the 1920s the Iraqi government also began to build public schools in the Jewish quarter; these were aimed at instructing Jewish students ${ }^{8}$ but these schools had no affiliation with the lay council of the Jewish community and therefore cannot be considered community schools because the community was not responsible for the curriculum or the funding, although the majority of the teachers in these schools were Jewish graduates of the communal schools. ${ }^{9}$

The argument that the education students received in the Jewish school system both enabled intercommunal understanding and prepared Jews to participate in public space itself has been discussed in great detail by authors such as Orit Bashkin, Abbas Shiblik, and Nissim Rejwan. ${ }^{10}$ Learning to read and write classical/standard Arabic was key to this participation. With access to Arabic literature and culture, Jewish students were able to engage with the emergent society as a whole, a phenomenon that Bashkin defines as practicing Arab Jewishness. ${ }^{11}$ It is my contention, however, that these schools, as institutions, were tools for the community to demonstrate its commitment to the nation and thereby become public spaces themselves, an idea not developed in the aforementioned works.

In this paper I equate Jewish Arabization with Jewish participation in the new public spaces both physically (such as employment in the civil service and teaching public schools) and intellectually during the Mandate and early years of the Iraqi state. Some striking examples of this are found in autobiographies. For example, it is during the Mandate period that we begin to find references to beloved children's books in Arabic and subscriptions to Arabic literary magazines. ${ }^{12}$ This is also the period during which the first Arabic language periodicals appeared in Iraq, most notably al-Hāssid and al-Misbāh, whose Jewish editors were graduates of the Alliance schools..$^{13}$ By receiving an education in formal Arabic youth were exposed to a dialect that was distinct from the JudeoBaghdadi spoken in Jewish homes, and this exposure prepared them for a life beyond the community. It allowed Jews who later joined the Iraqi civil service

Report of the Jewish Schools Committee on the Jewish Schools in Baghdad 1930, 6 CAHJP - Hebrew University doc. Iraq File-6382.

9 Abbas Shiblik, Iraqi Jews: A History (London: Saqi Books, 2005).

10 Bashkin, New Babylonians: A History of Jews in Modern Iraq (Stanford, CA: Stanford University Press, 2012); idem, The Other Iraq; Shiblik, Iraqi Jews; and Nissim Rejwan, The Jews of Iraq: 3000 Years of History and Culture (London: Weidenfeld and Nicolson, 1985).

11 Bashkin, New Babylonians.

12 Ibid., 23, 244.

13 Cohen, The Jews of the Middle East: 1860-1972, 125. 
and foreign companies to converse in a style similar to that of their non-Jewish colleagues. ${ }^{14}$ Finally, neither the faculty nor the student body of these schools was homogenous in composition, with the exception of the Midrash Talmud Torah. Records indicate that non-Jewish children, particularly those from the Chaldean community, were among the student body, although this tapered off in the 1930 s as more Christian schools were opened, as the Iraqi government began to open more state schools, and as the general level of public education improved. Finally, non-Jewish teachers were regularly employed in the Jewish schools, particularly for the study of Arabic. The interactions with non-Jewish students and faculty gave the Jewish students regular meaningful contact with individuals outside their community.

The schools were also tools of the community that served to show its loyalty to the monarch and the state. One example of this expression of loyalty can be seen in the schools' active participation in the pageantry of the state. For example, at the invitation of the community, King Faysal visited the Alliance Laura Kadoorie girls' school in 1924 with Ja'far al-'Askarī then prime minister of Iraq; they made a similar visit to the Rachel Shahmon community school a year later. Prince Ghazi, the minister of education at the time, attended the graduation ceremony of al-Wataniyya community school in $1925 .{ }^{15}$ And as Aline Schlaepfer ${ }^{16}$ discusses in her chapter, the Alliance school in Basra publicly mourned the death of King Ghazi in 1949 with teachers fashioning black armbands for the students and faculty to wear. These examples demonstrate the ways in which the schools, as institutions, were used to further the idea of the Jewish community as an integrated sector of Iraqi society.

As Hannah Mueller-Sommerfeld mentions in her chapter on the role of the League of Nations on the Mandate in Iraq, Jewish communal leaders, although initially desiring British citizenship, ${ }^{17}$ accepted the idea of being citizens in an Iraqi state, urged the community to be loyal citizens, and stressed integration as opposed to segregation; this is evidenced by the above-mentioned very public overtures within communal space. And yet, "Arabization" is only one side of the coin. The Jewish community also officially asked for the preservation of

14 Naim Kattan, Farewell Babylon (London: Souvenir Press, 1975), 11-16. This is evidenced in an anecdote he tells of a Jewish friend who speaks in the Judeo-Baghdadi dialect among their non-Jewish friends.

15 Bashkin, New Babylonians, 39.

16 I would like to thank Aline Schlaepfer for her invaluable suggestions in preparing this chapter.

17 Norman A. Stillman, Jews of Arab Lands in Modern Times (Philadelphia: Jewish Publication Society, 1991) $256-258$. 
the "free opportunity for economic and educational development" as the main pillars of their community, which guaranteed their history and communal life in Iraq. These requests were relatively mild compared to Assyrian hopes for independence, but were certainly in line with the rights that other religious and ethnic communities hoped to gain in the new state. ${ }^{18}$ It was this balance between integration into the new Iraqi society and the preservation of their communal identity that was key to the Jewish schools of Baghdad. Part of this preservation of communal identity went beyond the borders of Iraq, as some schools worked to forge what can be considered a modern Jewish identity, i.e., one not grounded in theology or local family bonds but based on a transnational Jewish identity. Thus the schools presented students with the ideas of Jewish nationalism, taught students about foreign Jewish communities, and gave students the opportunity to study abroad in foreign Jewish schools or with the help of scholarships from foreign Jewish humanitarian organizations. By understanding the fluidity between public and communal within these schools we can begin to understand how the Jewish community navigated between public and communal space within the Iraqi state.

\section{The Development of a Jewish School System}

On the eve of the Mandate the Jewish community was the oldest and most organized provider of secular education for boys and girls in Baghdad, the seeds for the system having been planted a century before. Although Jewish education in Baghdad had a long tradition, beginning with the fabled Abbasid-era yeshivot, ${ }^{19}$ these schools had ceased to exist by the eighteenth century, concurrent with the general decline of the city due to plague and political instability through the mid-nineteenth century. It was not until $183^{2}$ that a new religious school opened, the Midrash Talmud Torah, which educated 2,049 students divided into 27 classes; this was followed by the Baghdad Yeshiva in 1840 for students wishing to continue their education. These schools focused on religious instruction, teaching such as subjects as the Talmud, Zohar, and other religious works, but notably they also provided education in elementary Hebrew and

18 Müller-Sommerfeld, in this volume.

19 Yaron Ayalon and Ariel I. Ahram, "Baghdad," Encyclopedia ofJews in the Islamic World, ed. Norman A. Stillman (Leiden: Brill, 2010), 2:602-617; Brill online, accessed 11 April 2014: http://referenceworks.brillonline.com/entries/encyclopedia-of-jews-in-the-islamic -world/baghdad-SIM_ooo468. 
Arabic. ${ }^{20}$ Prior to attending the Midrash, young boys were sent to some thirty ustadhs, literally one-room schoolshouses where young boys received religious education by rote until they were old enough to help support their families or continue their education at the Yeshiva. The curriculum and hierarchy in these types of establishments was analogous to the Muslim and Christian educational options of the time, limited to boys whose parents could afford the school fees, they were organized either by schoolmasters in private homes or by the religious leadership in larger institutions and endowed by a waq set up by wealthy members of the community. Other options for education included apprenticeships for those entering trade or private tutoring for the wealthy. Although technically, girls could attend the ustadhs (but not the Midrash Talmud Torah) in reality, few if any girls ever attended. ${ }^{21}$ It is more likely that upper class girls received private tutoring, as the existence of correspondence by women from the nineteenth century demonstrates that some had the ability to read and write in both Hebrew and Latin scripts, although this was surely the exception. ${ }^{22}$

For the Jewish community this limited choice in education began to change when the Alliance Israélite Universelle opened its first school in Baghdad in 1864, at the request of members of the community who had heard about the recently opened Alliance boy's school in Tetouan, Morocco. By way of comparison, the first elementary school teaching secular subjects to Muslim boys in Baghdad was established in 1869 by Midhat Pasha. ${ }^{23}$ So although at the time of the British Mandate the Jewish community had developed the most extensive network of schools, the importance of modern education also had advocates in other religious communities in nineteenth-century Baghdad, albeit access to these schools was limited to a privileged few. The original Alliance school (later named in honor of Albert Sassoon) met with limited success; it closed shortly after it opened, then reopened a few years later. Protests from the religious authorities regarding the concept of secular education were relatively mild, it is possible that the Rabbinate did not feel threatened by the Alliance because of its small size and high school fees, in comparison the Midrash Talmud was less costly and better established. The end of the conflict between the Alliance school and the Rabbinate came when the chief

20 Maurice M. Sawdayee, The Baghdad Connection (Self published, 1991), 25; David Sassoon, The History of the Jews in Baghdad (London: Simon Wallenberg Press, 2006), 17.

21 Cohen, The Jews of the Middle East: 1860-1972, 114.

22 The Sassoon archives at Hebrew University have nineteenth-century correspondence from women in both Judeo-Arabic and French.

23 Rejwan, Jews of Iraq, 181. 
rabbi, Abdullah Somekh, sent his son to the Alliance school, although he himself was head of the Midrash Beit Zilkha, a branch of the Midrash Talmud Torah. ${ }^{24}$

When an Alliance girl's school opened in 1893, it was the first of its kind in Iraq. By 1920 Jewish schools enrolling both boys and girls had been established in Basra, Mosul, Hilla, 'Amara, and Kirkuk. Parallel to the expansion of the Alliance system, Jewish communities in Iraq began to build their own modern schools beginning with what was initially a coed school, Noam (also referred to as Haron Saleh) in ${ }_{1902 ;}{ }^{25}$ they also slowly integrated more secular subjects into the religious schools. ${ }^{26}$ Over time these new options made the role of the Alliance less important than in many other Jewish communities in the Islamic world, ${ }^{27}$ where often the Alliance schools were the only Jewish education option.

The ideology of the Alliance Israélite Universelle was to educate modern Jews to be productive members of modern society. ${ }^{28}$ This philosophy corresponded to the philosophy of the Jewish community and in particular the lay council with regard to the community's integration into the new Iraq during the early years of the Iraqi state. These schools represented one way that the local Jewish community could leverage their international connections for the betterment of their local community. The importance of this is twofold, first, these schools cannot be compared to missionary schools, whose objective, at least in part, was to convert their pupils and their families. The Jewish community actively requested that these schools be established and continued to seek guidance and aid from the Alliance Israélite Universelle, Anglo-Jewry Association, and later the Joint Distribution Committee even after the management of the schools had officially been transferred to the lay council's school committee. Once the management of the schools was under local authority, these organizations began to function as philanthropic organizations; they were no longer administrators offering grants both for the regular budget and for special initiatives. This continued support was essential to the stability and the growth of the schools, especially in the wake of the destruction wrought by World War I

24 Sasson Somekh, Baghdad Yesterday: The Making of an Arab Jew (London: Ibis Editions, 2007), 55. See also Schlaepfer in this volume.

25 Jewish Schools Report, tables, page 2.

26 The chief rabbi's office makes a note of this fact in its letter to Magnes.

27 Rejwan, The Jews of Iraq, 186.

28 Aron Rodrigue, "Alliance Israélite Universelle Network," EJIW, 1:171-180; Brill online, accessed 11 April 2014: http://referenceworks.brillonline.com/entries/encyclopedia-of-jews -in-the-islamic-world/alliance-israelite-universelle-network-COM_ooor6oo. 
and with the challenge of expanding education to a community where few had the means to pay fees and were therefore dependent on scholarships and other types of subventions. Second, the actions of these foreign philanthropists benefitted Iraqis of other confessions who either attended these schools or used the public health clinics (sometimes located in the school) that they were also instrumental in opening. In more general terms these schools played a role in educating the first generation of Iraqi civil servants (both Jewish and nonJewish). ${ }^{29}$ Therefore the presence of foreign Jewish philanthropy did not lead to increased sectarianism but benefitted the residents of Baghdad as a whole, beyond simple enrollment figures.

Although information exists as to the enrollment at the Alliance schools from their founding it is difficult to situate this information within a larger context as there is little reliable demographic information for the province of Baghdad from the Ottoman period and it is therefore difficult to estimate the number of Jews residing in Baghdad during the late nineteenth century. With that in mind we can safely state that although modern education was expanding in the Jewish community throughout the nineteen and early twentieth century, reaching more and more students each year, it remained limited to a privileged few; for example, in 1900 there were 296 boys and 166 girls enrolled in all of the Alliance schools in "Mesopotamia," the term the Alliance used when referring to the region prior to the formation of the Iraqi state. ${ }^{30}$ However, the community's decision to open its own schools with lower enrollment fees, in addition to expanding the capacity of the Alliance schools during the first two decades of the twentieth century, demonstrates the communal desire to reach a wider social spectrum of students. This desire is clearly stated in an English language report from the 193 os entitled Report of the Jewish Schools Committee on the Jewish Schools in Baghdad 1930. ${ }^{31}$

To understand the centrality of the Jewish schools to the community itself and to place the evolution of the Iraqi education system between 1920 and 1951 in context, it is important to compare the size of the Jewish community with that of the general population both as a whole and in relation to those who had access to education. In the early 1920 s the population of the city of Bagh$\mathrm{dad}^{32}$ was approximately 200,000 people. Of the general population there were

29 Shiblik, IraqiJews, 40.

30 Cohen, The Jews of the Middle East 1860-1972, 117. A complete table listing the children enrolled in Alliance schools is included.

31 Jewish Schools Report.

32 This number refers to the province of Baghdad, as opposed to the city itself. 
somewhere between 65,000 and 80,000 Jews living in the province of Baghdad, at least 55,000 of them living in the city of Baghdad itself. ${ }^{33}$ Proportionally, this means that a least a quarter of the city's population was Jewish, making the Jewish community the single largest religious/ethnic group in the city and as Nissim Rejwan (among others) argues, the best educated as a communal whole. ${ }^{34}$ In 1920 , the Jewish community of Baghdad lists seven primary and secondary schools plus three vocational schools educating 4,030 boys, 1,481 girls for a total of 5,521 pupils. ${ }^{35}$ By comparison, in 1920 in the whole of Iraq there were only 88 primary and 3 secondary schools (for a total of 8,110 students) for a national population of around 3 million. ${ }^{36}$

This means that during the 1920 a large percentage of those who received a modern education were Jewish. And as the Jewish schools dedicated more hours to the study of foreign languages the Jewish students had a strategic advantage over those educated in the public schools who received less training in English and French. One consequence of this was that the graduates of Jewish schools greatly benefitted from the British presence in Iraq during the British Mandate, as there was a sharp increase in white-collar employment opportunities with the increase in foreign companies in Baghdad, and an expanded civil service.

By the 1930s, educational opportunities for the general population had increased. The national population had grown to over 4.5 million inhabitants ${ }^{37}$ and it now had 335 primary and secondary schools with 27,467 male pupils 6,573 female pupils and an additional 293 children in coeducational kindergartens. The Jewish school system had also grown along with its population but not at the same speed as the nation. For a population of around 65,00o Jews in Baghdad, in the 1930 s there were ten primary and secondary schools with 5,031 boys and 2,151 girls plus an additional 700 poor girls receiving vocational training. ${ }^{38}$

33 Page 3 of a 1924 report from the office of the Chief Rabbi to Judah Magnes, in Jerusalem, p3/2464 Iraq plan CAHJP.

Rejwan, The Jews of Iraq, 210-211. Other groups included Sunn̄̄s, Shī̄is, Persians, Kurds, and Chaldeans.

35 Jewish Schools Report.

36 Batatu, The Old Social Classes and the Revolutionary Movements of Iraq, 35; Roderic D. Matthews and Matta Akrawi, Education in Arab Countries of the Near East: Egypt, Iraq, Palestine, Transjordan, Syria, Lebanon (Washington, DC: American Council on Education, 1949).

37 Batatu, The Old Social Classes and the Revolutionary Movements of Iraq, 40.

38 Jewish Schools Report CAHJP, Jerusalem. 
Based on the growth of the public schools between 1920 and 1930 one could postulate that the Jewish schools became less central to the community and the nation as a whole. This idea was suggested by scholars such as Shiblik and Twena, ${ }^{39}$ the main argument in support of this claim being the newly founded government schools. This assumption is corroborated by a 1930 school report from the Jewish lay council, which notes the establishment of a public boys school in the Jewish quarter ${ }^{40}$ and the relative stagnation in the number of boys attending the Jewish schools. ${ }^{41}$ Until this point those students unable to pay school fees or secure scholarships could only attend the Midrash Talmud Torah or a vocational program, neither of which offered the possibility to prepare for entrance exams for secondary schools, which in turn opened up the possibility of employment in foreign firms or the civil service-both channels to social mobility. And yet, the Jewish school system continued to expand as the table below indicates; therefore, it is impossible to argue that the Jewish schools lost their relevance in the wake of expanded public education. There are multiple reasons for the continued relevance of the Jewish schools. First, Jewish schools maintained higher academic standards, this was a result of the lower student-teacher ratio and the larger proportion of teachers with a secondary education. ${ }^{42}$ For secondary education the Jewish schools were among the few institutions that offered students the possibility to prepare for the French Baccalaureate (in the case of the Alliance schools), or the London matriculation examinations (in the case of Shamash school); other options in the city were private, primarily Christian, institutions with comparable school fees. ${ }^{43}$ Up until the dissolution of the community the Alliance schools and the Shamash school remained the gold standard of both primary and secondary education in Baghdad. This was particularly true in the opportunities they presented for girls. Finally, the continued communal investment resulted in lower school fees, and the free vocational opportunities for poor children and orphans all helped the schools to remain relevant. Even during the uncertainty of the 1940s and World War II, the Farhüd, ${ }^{44}$ and general political tensions between the Jewish community and the state, six new communal schools were

39 Shiblik, IraqiJews, 41.

40 Jewish Schools Report CAHJP, Jerusalem, 2.

41 The overall number of Jewish students increased between 1920 and 1930 as the small decline in the number of boys was offset by an increase in attendence by girls.

42 Cohen, The Jews of the Middle East 1860-1972, 121.

43 Matthew and Akrawi, Education in Arab Countries of the Near East, 209-213.

44 The Farhüd was the anti-Jewish riot that broke out in the wake of the coup d' etat in 1941; in it approximately 180 Jews were killed and millions of dollars in damage was sustained. 
built, including two between 1948 and $1949 .{ }^{45}$ With these facts in mind, it is clear that the Jewish schools remained crucial to the community. The opening of public schools worked to further expand the educational opportunities for Jewish youth but did not reduce the student base of the Jewish schools, which, as the table below illustrates, continued to grow steadily.

Schools under the supervision of the Jewish

community in Baghdad (primary and secondary)

\section{Year Number of schools Number of pupils}

\begin{tabular}{rrr}
\hline 1920 & 8 & 5,511 \\
1930 & 11 & 7,182 \\
1935 & 12 & 7,911 \\
1945 & 14 & 10,021 \\
1949 & 20 & 10,391 \\
\hline
\end{tabular}

See table in Cohen Hayyim J. ${ }^{46}$

Public Schools in Iraq (Primary \& Secondary)

\begin{tabular}{ccc}
\hline Year & Number of schools & Number of pupils \\
\hline 1920 & 91 & 8,111 \\
1930 & 335 & 36,595 \\
1940 & 791 & 104,490 \\
1945 & 949 & 108,945 \\
\hline
\end{tabular}

See table Matthew and Akrawi ${ }^{47}$

In the early twentieth century the Jewish schools faced challenges similar to those of the state run schools, namely a lack of funds and a lack of trained teachers. ${ }^{48}$ In a 1924 letter from the office of the chief rabbi to Judah Magnes (the first chancellor of Hebrew University), the secretary to the chief rabbi carefully

45 Shiblik, IraqiJews, 40.

46 Cohen, The Jews of the Middle East 1860-1972, 123.

47 Matthews and Akrawi, Education in Arab Countries of the Near East, 140.

48 Jewish Schools Report, 8; Stephen Hensley Longrigg, Iraq 1900 to 1950 (London: International Book Center: 1968), 110. 
explains the finances of the community. In the case of the Jewish community the most significant revenue came from the gabelle, essentially a tax levied on the sale of kosher meat. In addition to this, the community also received money from the rents on three buildings they owned and the sale of sheep intestine casings from slaughtered animals, all traditional sources of communal revenue ${ }^{49}$ For the purpose of financing education the community solicited external financial aid from wealthy Baghdadi Jews residing in the Far East (such as Albert Sassoon and Elias Kadoorie) and from foreign Jewish philanthropic agencies, specifically the aforementioned Alliance Israélite Universelle and the British Anglo-Jewish Association (established in 1871), and also from the American Joint Distribution Committee (established in 1914), thereby reinforcing their links to foreign Jewish communities. They also received regular contributions from the Iraqi government, however these funds were extremely limited, representing less than 4 percent of the annual budget. ${ }^{50}$

Overall, education was one of the main expenditures of the Jewish community; ${ }^{11}$ the communal organization of schools became more structured as the Rabbinate yielded considerable power to the lay council, which by 1920 was composed of white-collar professionals and merchants, the majority of whom were graduates of the Alliance and community schools. ${ }^{22}$ By the end of the 1920 s the Jewish community had a mature established school system, whereas the national education system in Iraq was still in its infancy. This is partially because the Mandate government allocated insufficient funds to education in Iraq for fear of developing an educated class that would be unable to find suitable employment. ${ }^{53}$ The Jewish schools surely suited the British, as these schools provided graduates from an indigenous community that was known for its sympathy towards the British presence in Iraq.

In addition to these challenges, the Iraqi ministry of education obviously faced challenges that were not shared by the Jewish community, particularly the fact that they had to deal with a larger more diverse population both geographically and culturally. Thus the Jewish school system was able to grow and expand their services faster to a larger segment of its population than the general school system; they built new schools, lowered general school fees, and provided more scholarships to meet the demands of the community. Even with

\footnotetext{
49 The chief rabbi's office makes a note of this fact in the letter to Magnes, 19.

50 Shiblik, IraqiJews, 40. Jews Schools Report, 1-3.

$5^{1}$ The chief rabbi's letter provides an overview of the budget, 20.

52 Shiblik, IraqiJews, 45 .

53 Peter Sluglett, Britain in Iraq: Contriving King and Country (New York: Columbia University Press, 2007), 193-194.
} 
the loss of students that resulted from some opting to attend public schools for financial reasons and others attending non-Jewish private schools after moving to new middle-class suburbs during late 1930 s and 1940 , ${ }^{54}$ the number of Jewish schools and students enrolled in them continued to grow up until the dissolution of the community at the end of the 1940s and early 1950s.

The Jewish schools consistently employed trained teachers who brought an international flavor to the profile of the schools. Initially, in the nineteenth century, the certified teaching staff in the Jewish schools was made up of foreign Jewish faculty, primarily teachers from other parts of the Muslim world who had been trained at the Alliance teacher's school in Paris. Once the community had its own graduates, they too began to fill the ranks of faculty in the schools, although some had little more than primary school training. In the 1920s the Jewish community took several steps to improve the quality of teaching in schools by sending local teachers to secondary education evening classes. And yet, the presence of foreign Jewish teachers remained prevalent in the schools well into the 1940s. Examples of this include the hiring of Mr. A.G. Brotman in 1926 to assist the schools' committee and oversee education, and in 1928 two additional teachers were recruited for the Shamash school, one from England and another from Beirut. Beginning in 1925 the community invited Jewish teachers from Palestine to Baghdad to instruct students in Hebrew language, literature, and Jewish history. All of the teachers from Palestine were eventually deported when the ministry of education prohibited the study of Modern Hebrew and Jewish history education in the communal schools in 1935; in addition the teaching of Zionism was banned. ${ }^{55}$ Even the local Jewish teachers brought an international flavor to the schools as many of those with higher education had been educated in Europe or elsewhere in the Middle East or even the United States. ${ }^{56}$

By the 1920 s the faculty of the Jewish schools also began to include nonJewish teachers. This was partly due to the paucity of Jewish teachers skilled in teaching Arabic language and literature. It appears, however, that well into the 1940s, the schools hired only Jewish headmasters, many of them trained in the United Kingdom or France. For example, the Alliance continued their policy

54 Somekh, Baghdad Yesterday, 47. An example of this is Sasson Somekh, whose family moved to Bustan al-Khass in 1937 where he attended a private elementary school run by a Christian woman for a few years until he later transferred to the Shamash high school.

55 Lev Hakkak, The Emergence of Modern Hebrew Literature in Babylon from 1735-1950 (West Lafayette, IN: Purdue University Press, 2009), 19.

$5^{6}$ Somekh, Baghdad Yesterday, 59. 
of employing former students from other areas of the Muslim world who had studied at the ENIO in Paris, whereas the Shamash school employed a series of British schoolmasters, the most well known being Emile Marmorstein and the aforementioned Adolf Brotman. Ironically, even as the Jewish schools began to hire more non-Jewish teachers, the public schools were pressured to employ Jewish teachers, particularly in the schools where the majority of students were Jews. This diversity of faculty greatly affected the students, giving them varying perspectives on the world at large, as the examples below illustrate.

Sasson Somekh received his introduction to Iraqi politics from his Arabic language and literature teacher at the Shamash school, Muhammad Sharara. Somekh recalls Sharara eschewing semi-official government textbooks in favor of lectures in which he could share his leftist political views - this was in the late 1940 s when those suspected of having communist affiliations were imprisoned or even executed. ${ }^{57}$ Teachers also brought the concept of Jewish nationalism into the classroom, sometimes in very subtle ways. Violette Shamash, who attended the Alliance Laura Kadoorie school in the 1920s, remembers her teacher Mme. Sabbagh, from Paris, teaching the children Hatikva, the then unofficial anthem of the Zionists in Palestine; it was only later in life that she learned the significance of the song. ${ }^{58}$

The influence of teachers on students was of course also found in public schools. In his biography, Nissim Rejwan recalls the days he attended Madrasat Ras El-Qarya. Ras El-Qarya was one of the public boys' schools in the Jewish quarter that catered almost exclusively to Jewish students and for the most part employed only Jewish teachers. Rejwan recalls a teacher named Dawood Afandi who taught Hebrew Bible. ${ }^{59}$ Afandi, according to Rejwan, devoted a whole lesson in the spring of 1933 to a discussion of the need to boycott German products in solidarity with the Jews of Germany. ${ }^{60}$ This anecdote illustrates how even in a government run school a classroom could become the place of a communal discussion; the idea of boycotting Germany had developed outside Iraq and was imported by Zionist circles present in Baghdad. It also offers an

57 Ibid., $77-80$.

58 Violette Shamash, Memories of Eden (Surrey: Forum, 2008) 35-36. Shamash mentions the teacher being from Paris although given her last name and the average profile of an Alliance teacher it is more likely that she was originally from somewhere in North Africa and was educated at the ENION in Paris.

59 Rejwan refers to the teacher as Dawood Afandi, however it is likely that Afandi simply refers to his title.

6o Nissim Rejwan, The Last Jews in Baghdad: Remembering a Lost Homeland (Austin: University of Texas Press, 2004), 59-6o. 
example of a teacher discussing a very sensitive political subject, even as certain factions in the Iraqi government were professing Nazi sympathies, primarily in protest against British colonialism.

\section{Curriculum}

The first Alliance school in Baghdad followed the Franco-Ottoman education model. Neither Arabic, the local language, nor Ottoman Turkish, the language of the administration, was central to the curriculum although both were taught to varying degrees through the nineteenth and early twentieth century. Originally, when the Alliance girl's school was opened in 1893, Arabic was not part of the curriculum. This is not surprising as during the Ottoman period the language of instruction in the Muslim schools was Turkish. ${ }^{61}$ And even in 1919 of the 75 public primary schools in Iraq only 56 taught in Arabic, 11 taught in Turkish, 7 taught in Kurdish, and one taught in Persian. ${ }^{62}$

It was not until the 1920 s that Iraqi state legislation began to mandate the study of Arabic. In 1924, in written correspondence from the office of the chief rabbi to Magnes in Jerusalem, we see notes that the government was pressuring the schools to teach in English and Arabic, but that the schools were slow to deviate from the curriculum developed by the Alliance. Although by this time the majority of Jewish schools were already teaching some Arabic, this educational legislation, in addition to the growing importance of Arabic in commerce and civil society, led to an increase in Arabic instruction throughout the Jewish schools. By 1930 all Jewish schools in Baghdad taught Arabic and all but one taught English. The one school not teaching English was the Alliance girl's school, Laura Kadoorie, where French was the main language of education, and Arabic was a distant second. If Laura Kadoorie represents one extreme in language division, it is also far from the exception: instruction in Arabic was not uniform throughout schools, grades, or genders, with schools allocating anywhere from 6 to 20 hours a week towards the study of Arabic. ${ }^{63}$

The lay council report of 1930 provides a clear breakdown of the subjects studied divided by language and providing the number of hours dedicated to each language for all but the Midrash Talmud Torah. By 1930 four schools were being administered by the Alliance Israélite Universelle, Albert Sasson

\footnotetext{
61 Sluglett, Britain in Iraq, 197.

62 Longrigg, Iraq 1900 to $1950,110$.

63 See lay council curricula tables.
} 


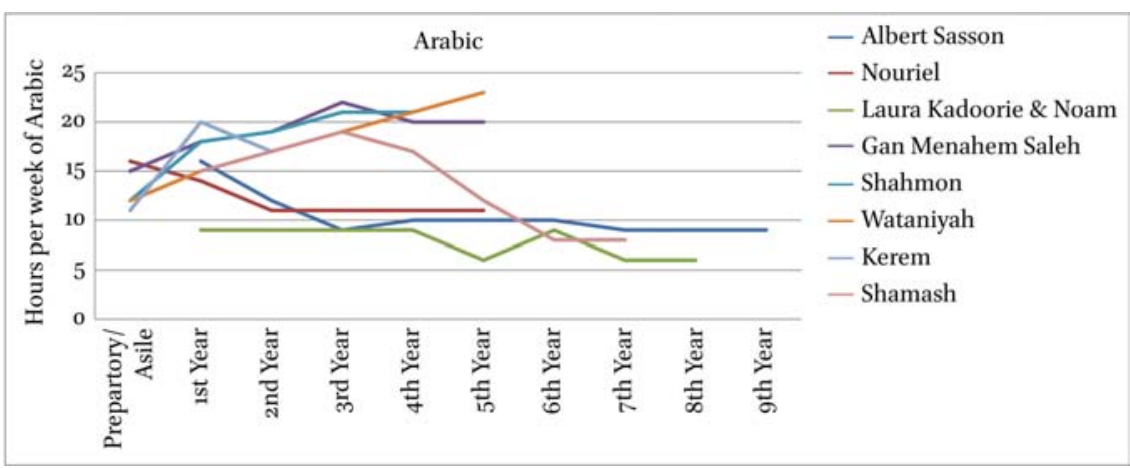

FIGURE 4.1

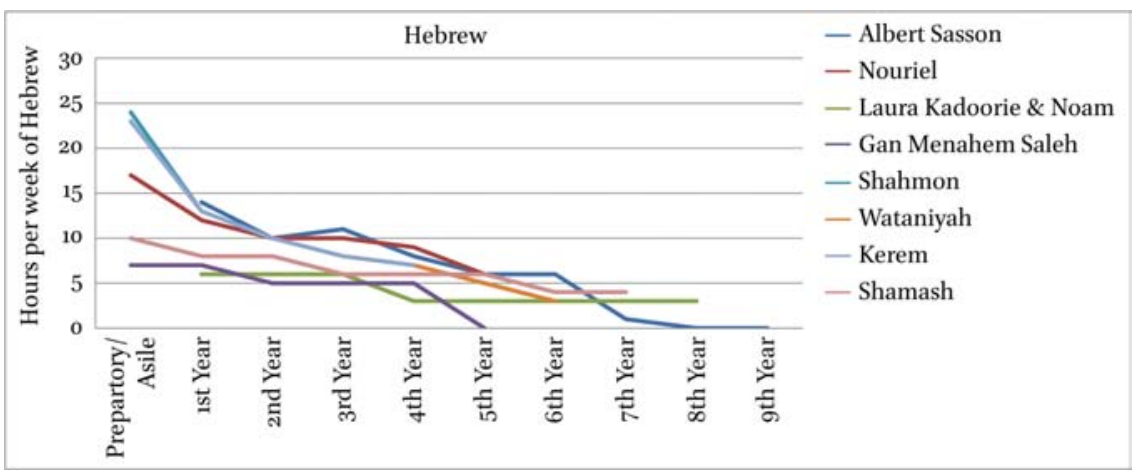

FIGURE 4.2

(founded in 1863), Nouriel (founded in 1902), Noam (founded in 1902), and Laura Kadoorie (founded in 1895). At the Alliance boy's schools, Albert Sasson and Nouriel, the curriculum was divided between Arabic, French, Hebrew, and English, with French and Arabic being the dominant languages. The allocation of hours per language was such that as a student neared matriculation, the time allocated to French would increase as the time for Arabic would decrease. For the less dominant languages such as Hebrew and English, hours allocated to Hebrew would decrease as hours allocated to English would increase. The Alliance girls' schools operated in a strikingly different way than what we see in this report. At Laura Kadoorie and Noam the dominant language during the entire duration of study was French, with Arabic second, and Hebrew far behind.

For the community run schools there was significantly more Arabic in the curriculum from their inception, regardless of gender. In addition, all of the schools dedicated substantial time to the study of Hebrew and English. The only communal schools which offered hours in French, and then only in the 


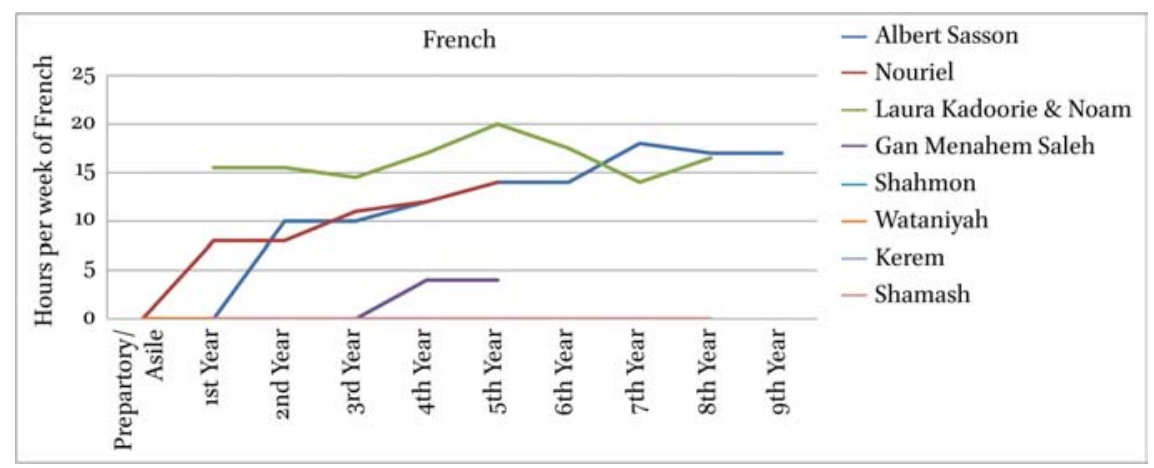

FIGURE 4.3

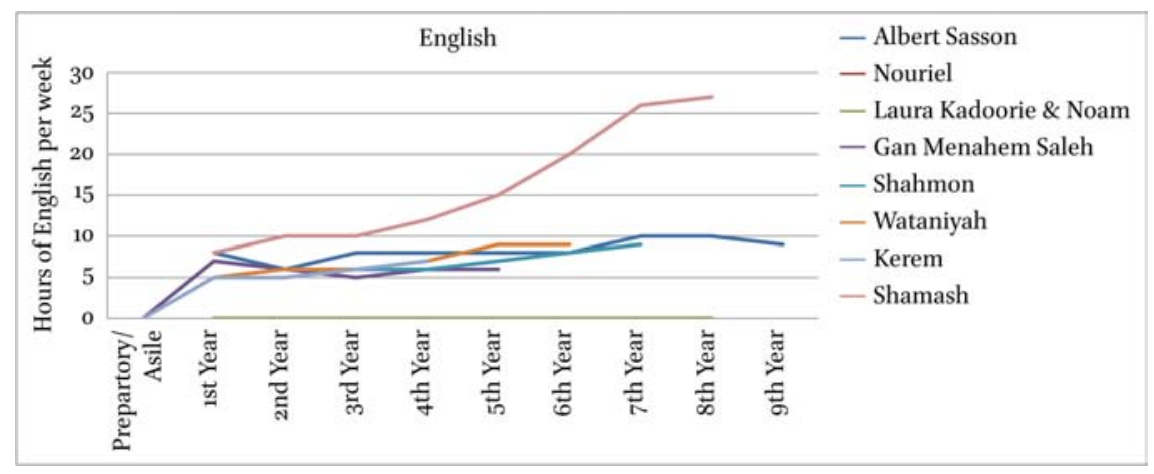

FIGURE 4.4

final two years, was the girl's school Gan Manehem Daniel Saleh (founded in 1910); it offered four hours per week in the final two years, most likely to prepare girls who wished to continue their education through year eight at the Alliance Laura Kadoorie school, the only Jewish girl's school offering courses for the final three years of secondary education. For the boy's community schools, Shahmon (founded 1909), Wataniyya (founded 1923), and Kerem (founded in 1924), Arabic was the dominant language. In the first years of education more time was allocated to English, though this slowly reversed as students progressed. Finally, Shamash (founded in 1928), which was also a community school but with an objective of preparing students to take the London matriculation exams, focused almost exclusively on English in the later years. Figures 4.1-4.4 compare the hours of study allocated to each language based on the numbers provided from the 1930 report.

When grouping the Alliance and communal schools together, the clearest differentiation in curriculum is between the sexes. Arabic was not universally included in the girl's curricula until much later, a point illustrated in Sasson 
Somekh's autobiography when he writes about the experience of his parents at the Alliance schools. Born in 1909 Somekh's mother learned to read and write in French and English at the Alliance girl's school in Basra, but was never taught to read or write Arabic. His father, born in 1900 and educated at the Alliance boy's school in Baghdad, studied European languages in addition to Arabic. ${ }^{64}$ This contrast relates to the fundamental philosophical differences between boy's and girl's education in the Jewish community. Whereas boys were educated to be successful in their chosen careers, have the means to support their future families, and participate as active citizens of the state, a women's role was much more limited. The impetus behind educating Jewish girls was based on the ideas of nineteenth- and early twentieth-century bourgeois society in western Europe and America. A girl's education was supposed to develop the qualities she needed to become a wife and homemaker, girls were essentially educated in domesticity. Education was synonymous with social prestige, making an educated girl a more desirable match on the marriage market. ${ }^{65}$

Girls' education began to change in the 1930 shen some occupations became open to women, such as teaching and nursing. However the difference in focus between boys' and girls' education is still evident when looking at the gender divide in the curricula of 1930 . The clearest indicator of this is the importance of the Arabic language in boys' education compared to girls' education, but there were other differences as well. In general, boys had three to six more hours of class time per week than girls and more time was dedicated to the "hard sciences," whereas girls dedicated significant time to subjects like embroidery, sewing, hygiene, and home economics.

These differences in and of themselves are not particularly surprising, given the role of women in Iraq at the time. However, if we consider standard Arabic as one of the main facilitators and markers of national identity, it is surprising that this was deemed more important for boys than for girls. One can postulate that, initially, the study of Arabic was not ideological but pragmatic-it was necessary for employment in the civil service and in commerce in the $1920 \mathrm{~s}$ and early 1930s. As upper and middle class women were not expected to work, the importance of mastering Arabic was seen as less important. This fact is illustrated in a 1924 letter written by David Sasson, ${ }^{66}$ then a teacher at the

64 Somekh, Baghdad Yesterday, 55-56.

65 Esther Meir-Glitzenstein, Zionism in an Arab Country: Jews in Iraq in the 194os (London: Routledge, 2004), 117-118.

66 Sasson (no relation to the Baghdadi Sassoon Family) was a Persian born Jew educated at the Alliance school in Tehran and the Alliance ENIO in Paris. 
Alliance girl's school, in which he deplores the fact that families prefer for their daughters to learn English over Arabic, even though English has less practical use for these women. He goes on to note that girls who are not taught to read Arabic will become women completely dependent on their fathers and spouses. ${ }^{67}$ Eventually this changed: by 1930 Laura Kadoorie had dropped the study of English in favor of Arabic, although only 6 to 9 hours a week were allocated to the language.

In the 1930s the only girls who received a comprehensive education in Arabic were those attending the one community girl's school, Gan Menahem Daniel Saleh. These girls received up to 22 hours of Arabic a week, making it the dominant language of their education. However Gan Menahem Daniel Saleh represented a minority of those girls who received an education, as the school only had 306 students compared to the two Alliance girl's schools that enrolled, in total, 1,826 students. ${ }^{68}$ As Arabic became a symbol of the nation and represented unity and integration, the number of hours dedicated to Arabic increased for girls, particularly in the 1940s. We cannot know whether the increase in Arabic was designed to facilitate women's integration into Iraqi society, or if the community wanted to demonstrate its commitment to Arabic, or whether it was a result of simple pressure from the government ministry of education, we do know, however, that it was an example of the growing importance of Arabic as an Iraqi national symbol.

Beyond the gender divide, the other major difference in curriculum was between the "religious" and the "secular" communal schools. Although all of the secular Jewish schools taught Hebrew, Jewish history, and religious studies, a point regularly mentioned in the Jewish schools report, they remained focused on a secular education. Obviously, the two branches of the Midrash Talmud Torah had a very difference perspective: linked directly to the rabbinate and only open to boys, they offered the least "modern" education. The 1930 lay council report does not discuss the curriculum of the Midrash Talmud Torah in the same detail as it does the other schools, yet it does mention that in addition to being a religious school it offered elementary studies in Arabic. The teaching of Arabic was most likely due to government pressure; after all, in the 1920 s the members of the communities attempted to persuade the rabbis to include more secular subjects, but the initiative was largely unsuccessful. In general, the Talmud Torah provided the lowest quality education among the Jewish schools. This was due not only to the lack of breadth in the curriculum but also

67 Monique Nahon, Hussard de l'alliance (Paris: Editions du Palio, 2010), 84.

68 Jewish School Report, 3. 
to the overcrowded classes and the lack of qualified teachers, and little changed in the school over the course of a century. It was also the most isolated from Iraqi society. And yet the religious schools did not close, and continued to have overcrowded classes until the 1950s. Knowing that the general bias of the community was toward modern education it is surprising the Midrash continued to attract students. Somewhere between 1925 and 1930 the Midrash abolished all school fees, thereby providing an option to those who could not afford the fee-based Jewish schools and were weary of sending their children to public schools. The abolishment of fees was perhaps their attempt to remain relevant in the wake of the secular Jewish schools and the free public schools. It was not until 1935 that a modern Talmud Torah was opened that offered a traditional religious education, taught secular subjects from the state curriculum, and prepared students to take the entry exams for secondary education. This school was relatively successful, and is a testament to the fact that it was not opposition to religious education that turned people away from traditional education, but a desire for a modern education for their children. However the student body continued to be made up of boys from poor families, from which we can infer that the Midrash was not the first choice for schooling among Baghdadi Jewish families. ${ }^{69}$

Beyond the actual curriculum, these schools were social spaces that allowed linguistic creativity in all languages to flourish. The school was a place that allowed students to interact with others outside their family circle and to practice languages not regularly spoken at home. The alliance archives are replete with elegant essays written in French by students comparing themselves to heroes and heroines of French literature or equating Jewish Iraqi history with French history. Although I have primarily focused on the study of English and French versus Arabic, Modern Hebrew also flourished in Iraq. This is due in great part to its instruction in the Jewish schools, although formally forbidden after 1935 it continued to be taught as biblical Hebrew. ${ }^{70}$ Lev Hakkak's book on modern Hebrew creativity in Iraq offers many examples of students experimenting with the Hebrew language during the 1920s and 1930s, the best example being the Shammash school's Hebrew language periodical, Shemesh. The school newspaper, written in Modern Hebrew and using Modern Hebrew script, only lasted three years, but throughout that time was read throughout the community. ${ }^{71}$

\footnotetext{
69 Cohen, The Jews of the Middle East: 1860-1972, 115.

70 Hakkak, The Emergence of Modern Hebrew Literature in Babylon, 189-190.

71 Ibid., $18-20$.
} 
Linguistic creativity in Arabic in the schools is perhaps best demonstrated through the "pageantry of the state," these were the official ceremonies referenced earlier, in which students would read poems by famous Arab poets, sing traditional Arab songs, and give speeches demonstrating their loyalty to the nation and the monarchy. In some cases students composed their own poems, a testament to the high level of Arabic they had been taught. This multilingual education benefitted Iraqi society as a whole, as it was the graduates of these schools who were responsible for translating many of the great works of European philosophy and history into Arabic.

\section{Conclusion}

The Jewish community of Baghdad during the Mandate and early years of the Iraqi state continued to function with the large measure of communal autonomy that it had for centuries prior, even as its constituents became more integrated into the new Iraqi nation. The Jewish community, led in tandem by the religious and lay councils, continued to levy taxes, act as the official representative of the community, and most importantly for our discussion, invest heavily in the development of educational institutions. From this statement it would be easy to assume that those schools attached to the Jewish community were insular in nature or that their objective was to foster a purely communal identity. However, on closer inspection, we see that this is not the case. Instead, the public policy of the Jewish community was to embrace the idea of the new Iraqi nation and the Jewish community's place in this new nation.

The Jewish schools were a tool to demonstrate this ideology both in their principles but also as physical spaces in which the community could learn about and engage with the greater nation. Schools were not, however, uniform in their curricula: students received varying levels of access to Arab, Western, and Jewish culture. The differences between individual schools is most clearly delineated through the number of hours dedicated to the study of different languages and the importance placed on secular subjects. Although it is clear that the schools were agents of Arabization, and in this capacity acted as public spaces, this is only one aspect of their identities. It is more accurate to state that Jewish students were given the tools to participate in the new state and society that was being built, and they were also exposed to Western ideas and Jewish culture. However, the extent of their exposure to these different cultures and ideals varied based on gender and socioeconomic status. In very broad terms, middle class males received the greatest exposure to Iraqi society either by attending the community school or later public schools. The poorer families 
were more likely to send their boys to the Midrash Talmud Torah, the program with perhaps the least external exposure or to communal vocational programs available for both boys and girls.

The Jewish schools of this period were remarkable in that they were able to produce Iraqi citizens who identified themselves with Arab nationalism, who not only participated in the nascent secular society but also at times became active architects of it. ${ }^{72}$ That being said, not all students received the same degree of exposure to Arabic or the ideals of the new state. The most striking difference, as mentioned earlier, is one of gender: on average less of the curriculum for girls was dedicated to Arabic and they were taught by fewer non-Jewish teachers. Girls also tended to leave school earlier than boys to marry and this abbreviated education plus the reduced hours for the study of Arabic limited their introduction to public debates. And yet, over time, even girls began to have increased access to Arabic, the ideals of the nation, and public space in general. As Bashkin notes, some Jewish girls did attend government schools, particularly in the 1940 os when more options were available, and it was becoming socially acceptable for women to appear in public unveiled..$^{73}$

The other difference in education was subtler, and relates to socioeconomics. Although the school committee was cognizant of the prohibitive expense of schools and endeavored to provide scholarships and a sliding scale for tuition, it never altogether abandoned fees for the Alliance or the community schools, rather it offered scholarships for the best students. Therefore families not able to afford these fees and not offered scholarships were faced with two diametrically different options, either the free religious school that offered little by way of secular education, or the public schools that were outside the community and provided less exposure to foreign languages and therefore Western society. The fact that the religious schools continued to exist is evidence that some families still chose to forgo a secular education and exposure to secular society in favor of having their children attend a Jewish school. However, even in this construction there was flexibility: it was not unheard of for children to change schools throughout their studies or to hire tutors for religious education. ${ }^{74}$

72 For a detailed discussion of the reception of the idea of the nation among Iraqi Jewish intellectuals see the unpublished 2012 doctoral dissertation, Aline Schlaepfer, "A Bagdad je resterai! Réception et diffusion du concept de 'nation' chez les intellectuels juifs de Bagdad entre la révolution jeune-turque et l'émigration (1908-1951)," (PhD diss., University of Geneva, 2012).

73 Bashkin, New Babylonians, 87-88.

74 Schlaepfer, “A Bagdad je resterai!," 42. 
In summary, in Iraq from the beginning of the Mandate period the boundaries between communal space and public space became increasingly blurred. Given the diversity of students that the Jewish schools of Baghdad produced and the fluid way in which the space functioned, it is clear that these schools were able to function both as public and communal space. For the Jewish community of Baghdad, schools were a tool with which the community could make itself relevant to the new nation while preserving its communal identity.

\section{Archival Documents}

Report from the office of the Chief Rabbi to Judah Magnes in Jerusalem dated 1924. CAHJP - Hebrew University, Jerusalem doc. Iraq File p3/2464.

Report of the Jewish Schools Committee on the Jewish Schools in Baghdad 1930. СAHJP—Hebrew University, Jerusalem doc. Iraq File—6382.

\section{Secondary Sources}

Ayalon, Yaron and Ariel I. Ahram. "Baghdad." Encyclopedia ofJews in the Islamic World. Executive Editor Norman A. Stillman. Leiden: Brill, 2010. Vol. 2, pp. 602-617.

Bashkin, Orit. New Babylonians: A History ofJews in Modern Iraq. Standford, CA: Standford University Press, 2012.

. The Other Iraq. Standford, CA: Standford University Press, 2008.
. "'Religious Hatred Shall Disappear from the Land' Iraqi Jews as Ottoman Subjects, 1864-1913." International Journal of Contemporary Iraqi Studies 4, no. 3 (2010), 308. (doi:10.1386/ijcis.4.3.305_1).

Batatu, Hanna. The Old Social Classes \& The Revolutionary Social Movement in Iraq. Princetion, NJ: Princeton University Press, 1989.

Cohen, Hayyim J. The Jews of the Middle East: 1860-1972. Jerusalem: Israel University Press, 1974.

Hakkak, Lev. The Emergence of Modern Hebrew Literature in Babylon from 1735-1950. West Lafayette, IN: Purdue University Press, 2009.

Kattan, Naim. Farwell Babylon. London: Souvenir Press, 1975.

Longrigg, Stephen Hensley. Iraq 1900 to 1950. London: International Book Center, 1968. Matthews, Roderic D. and Matta Akrawi. Education in Arab Countries of the Near East: Egypt, Iraq, Palestine, Transjordan, Syria, Lebanon. Washington, DC: American Council on Education, 1949.

Meir-Glitzenstein, Esther. Zionism in an Arab Country:Jews in Iraq in the 1940s. London: Routledge, 2004. 
Nahon, Monique. Hussard de l'alliance. Paris: Editions du Palio, 2010.

Rejwan, Nissim. The Jews of Iraq: 3000 Years of History and Culture. London: Weidenfeld and Nicolson, 1985 . . The Last Jews in Baghdad: Remembering a Lost Homeland. Austin: University of Texas Press, 2004.

Rodrigue, Aron. "Alliance Israélite Universelle Network." Encyclopedia of Jews in the Islamic World. Executive Editor Norman A. Stillman. Leiden: Brill, 2010. Vol. 1, pp. 171180.

Sassoon, David. The History of the Jews in Baghdad. London: Simon Wallenberg Press, 2006.

Sawdayee, Maurice M. The Baghdad Connection. Self published, 1991.

Shamash, Violette. Memories of Eden. Surrey: Forum, 2008.

Shiblik, Abbas. Iraqi Jews: A History. London: Saqi Books, 2005.

Sluglett, Peter. Britain in Iraq: Contriving King and Country. New York: Columbia University Press, 2007.

Somekh, Sasson. Baghdad Yesterday: The Making of an ArabJew. London: Ibis Editions, 2007.

Stillman, Norman A. Jews of Arab Lands in Modern Times. Philadelphia: Jewish Publication Society, 1991.

Wattenpaugh, Keith D. Being Modern in the Middle East: Revolution, Nationalism, Colonialism and the Arab Middle Class. Princeton, NJ: Princeton University Press, 2006. 